\title{
COMMENTARY
}

\section{THE DOMESTICATED LIBERTY OF LAWRENCE $V$. TEXAS}

\author{
Katherine M. Franke*
}

In this Commentary, Professor Franke offers an account of the Supreme Court's decision in Lawrence v. Texas. She concludes that in overruling the earlier Bowers v. Hardwick decision, Justice Kennedy does not rely upon a robust form of freedom made available by the Court's earlier reproductive rights cases, but instead announces a kind of privatized liberty right that affords gay and lesbian couples the right to intimacy in the bedroom. In this sense, the rights-holders in Lawrence are people in relationships and the liberty right those couples enjoy does not extend beyond the domain of the private. Franke expresses concern that Lawrence risks domesticating the gay and lesbian civil rights movement. She argues that the limited scope of the Lawrence opinion, as well as the gay community's reaction to it, can be traced, in large part, to the palimpsestic presence of Bowers in the opinion and in the political organizing that has followed it.

\section{INTRODUCTION}

In significant ways, this has been a breakthrough year for the gay and lesbian rights movement. Canada and the Commonwealth of Massachusetts have legalized same-sex marriage, while thousands of gay and lesbian couples have been issued marriage licenses in San Francisco. The Episcopal Church anointed its first openly gay bishop, and the United States Supreme Court found sodomy laws unconstitutional. ${ }^{1}$ Then of course there's Queer Eye for the Straight Guy and The L Word.

Gay rights activists and scholars have rejoiced at these victories. Indeed, some have gone so far as to label the decision in Lawrence $v$. Texas "our Brown." Immediately after the decision was announced, Lambda

* Professor of Law, Columbia University School of Law. For helpful comments, questions, discussions, and suggestions, I am grateful to Ariela Dubler, Renée Römkens, Teemu Ruskola, Arun Subramanian, and Jeremy Waldron. Patricia Wencelblatt provided invaluable research assistance. An earlier version of this Commentary was delivered in the fall of 2003 at the Sexual Worlds, Political Cultures conference in Washington D.C. celebrating the 20th anniversary of the publication of historian John D'Emilio's Sexual Politics, Sexual Communities. The radical sexual rights agenda of the early homophile movement that D'Emilio described in this book continues to influence my thinking about the nature of gay rights organizing today.

1. Lawrence v. Texas, 123 S. Ct. 2472 (2003).

2. For comparisons between Laurence and Brown, see William N. Eskridge, Jr., Yale Law School and the Overruling of Bowers v. Hardwick, 51 Yale L. Rep. 36, 36 (2004); Tobias Barrington Wolff, Political Representation and Accountability Under Don't Ask, Don't Tell, 89 lowa L. Rev. (forthcoming 2004) (manuscript at 61-66, on file with the Columbia Law Review); E.J. Graff, The High Court Finally Gets It Right, Boston Globe, June 29, 2003, at D11; High Court Busy as Term Ends, CBS News, May 30, 2003, available at http://www. 
Legal's legal director delighted in a press release: “[This] landmark victory ... recognizes that love, sexuality and family play the same role in gay people's lives as they do for everyone else." 3 The ACLU proclaimed: "It gave us the constitutional right to form intimate relationships and to sexual expression. For that, Lawrence changes everything." ${ }^{4}$ Everything? That may overstate the significance of the case somewhat. But what did Laurence do-as a matter of freedom, as a matter of rights, as a matter of sexual politics? What kind of emancipatory horizon was opened up by the Supreme Court's decision in Lawrence?

In this commentary I provide a critical reading of both the Lawrence opinion and the gay community's response to it. I argue that in Lawrence the Court relies on a narrow version of liberty that is both geographized and domesticated-not a robust conception of sexual freedom or liberty, as is commonly assumed. In this way, Lawrence both echoes and reinforces a pull toward domesticity in current gay and lesbian organizing. This gravitational pull, in important respects, can be understood as the residue of Bowers $v$. Hardwick. Teemu Ruskola points out that "insofar as the Hardwick Justices asserted patently counterfactually that there is ' $\mathrm{n}$ ]o connection between family, marriage, or procreation on the one hand and homosexual activity on the other,' it was important to remind the world that gay people, too, have families." 5 Thus, although Lawrence unambiguously reversed Bowers in a formal legal sense, it did not, and of course, could not, erase it from our cultural and political landscape ${ }^{6}{ }^{\text {Yet }}$ the gay community finds itself invested in a politics that remains in dia-

cbsnews.com/stories/2003/05/30/supremecourt/main556319.sbtml (on file with the Columbia Law Review) ("For the gay community, Lawrence is their Brown v. Board of Education, tbeir major civil rights case." (quoting Georgetown University Law Center Professor Richard Lazarus)); Adam DeBaugh, The LGBT "Threat" to Straight Marriage, at bttp://www.whosoever.org/v8i2/marriage.shtml (last visited Apr. 10, 2004) (on file with the Columbia Law Review) ("This has already been called our Broum . . . .). Nan Hunter provides a thoughtful reading of the parallels between Lawrence and Brown in Living with Laurence, 88 Minn. L. Rev. (forthcoming 2004) (manuscript at 1124-25, on file with the Columbia Law Review). Professor Hunter takes the view that to call Lawrence "our Brown" underappreciates the rhetorical power of Justice Kennedy's articulation of the liberty right in Lawrence as compared with the rather miserly, if not cryptic, language used by Justice Warren in Brown.

3. Lambda Legal, Lawrence and Garner v. Texas: Landmark Victory!, at http://www. lambdalegal.org/cgi-bin/iowa/cases/record?record=93 (last updated June 26, 2003) (on file with the Columbia Law Review).

4. American Civil Liberties Union, Why the Supreme Court Decision Striking Down Sodomy Laws Is So Important, at http://www.aclu.org/LesbianGayRigbts/LesbianGay RightsMain.cfm (last visited Apr. 10, 2004) (on file with the Columbia Law Review) [hereinafter ACLU].

5. Teemu Ruskola, Gay Rights vs. Queer Theory: What Is Left After Lawrence v. Texas, $23 \mathrm{Soc}$. Text (forthcoming 2005) (manuscript at 10, on file with the Columbia Law Review) (quoting Bowers v. Hardwick, 478 U.S. 186, 191 (1986)).

6. Nan Hunter disagrees with this assessment. She writes that in Laurence, "one senses that this Court was removing a stain as well as a precedent." Hunter, supra note 2 (manuscript at 1125-26). 
logue with Bowers' particular forms of homophobia and heterosexism. The ACLU's comments praising Lawrence provide evidence of this very problem: "Lawrence gives us a political argument for all the things we want to change: since the Constitution protects our relationships, the government has a moral duty to protect us when we are attacked because of them."7

The challenge after Bowers's repudiation is to lend meaning to Lawrence, in particular, and sexual politics, in general, in such a way that exceeds the shadow of Bowers. One way to frame this question is to ask: How would we have wanted the Supreme Court to invalidate the Texas sodomy law if Lawrence had been the Court's first attempt to chart the constitutional significance of sodomy laws? In this respect, gay rights lawyering and activism have been insufficiently attentive to the palimpsestic presence of Bowers in the wake of Lawrence.

\section{Lawrence's Privatized Liberty}

Unquestionably, Lawrence is an about-face in the Supreme Court's interpretation of the Constitution's application to the lives and practices of gay men and lesbians. The Court explicitly and unequivocally repudiated its prior jurisprudence ${ }^{8}$ in declaring that sodomy laws violate the U.S. Constitution. While it was widely expected that the Court would find the Texas sodomy law unconstitutional, the sweeping-indeed movinglanguage that Justice Kennedy uses in the majority's opinion came as quite a surprise. The Texas statute "demeans the lives of homosexual persons," he writes. 9 The plaintiffs "are entitled to respect for their private lives. The State cannot demean their existence or control their destiny by making their private sexual conduct a crime." 10 This soaring language recognizes the dignity and respect that gay men and lesbians are due. However, the Texas sodomy statute was not found to violate a constitutional right to dignity, but rather a right to liberty.

That said, it is a curious form of liberty that Justice Kennedy reaches for in Lawrence. "Liberty protects the person from unwarranted government intrusions into a dwelling or other private places," he writes. "Freedom extends beyond spatial bounds. Liberty presumes an autonomy of self that includes freedom of thought, belief, expression, and certain intimate conduct." 11 Yet the liberty principle upon which the opinion rests is less expansive, rather geographized, and, in the end, domesticated. It is not the synonym of a robust liberal concept of freedom. ${ }^{12}$

7. ACLU, supra note 4 .

8. See Bowers, 478 U.S. at 195.

9. Lawrence v. Texas, 123 S. Ct. 2472, 2482 (2003).

10. Id. at 2484 .

11. 1d. at 2475 .

12. To resolve any confusion at the outset as to whether the case was decided on grounds of privacy, liberty (both as a matter of substantive due process), or equality (under the Equal Protection Clause), Justice Kennedy makes clear that "[ $t]$ he instant case involves 
Justice Kennedy's use of "freedom" indicates his inclination to understand it as an overarching philosophical concept, a way of being that is made up of aggregate forms of liberty or liberties. Thus, he begins Law rence by noting that "[f]reedom extends beyond spatial bounds," while "[l]iberty protects the person from unwarranted government intrusions into a dwelling or other private places." 13 This conception of liberty departs, rather significantly, from the account of liberty relied upon by the Court in Planned Parenthood v. Casey, where in an opinion written jointly by Justices Kennedy, O'Connor, and Souter, liberty is likened to a thick form of autonomy: "At the heart of liberty is the right to define one's own concept of existence, of meaning, of the universe, and of the mystery of human life. Beliefs about these matters could not define the attributes of personhood were they formed under compulsion of the State."14 Although Justice Kennedy states up front in Lawrence that " $[t]$ he instant case involves liberty of the person both in its spatial and more transcendent dimensions," 15 his reasoning depicts a more confined conception of liberty than this opening line suggests.

liberty of the person." Id. Indeed, the first word of the majority opinion is "[1]iberty." Id. Furthermore, Kennedy explains that the liberty contemplated by Laurence is in some way a subset or constitutive element of an expansive notion of freedom. In the opening passage of the Lawrence opinion, Justice Kennedy seeks to draw a distinction between liberty on the one hand and freedom on the other. When discussing the relevance of non-U.S. jurisprudence, he observes that "[t]he right the petitioners seek in this case has been accepted as an integral part of human freedom in many other countries." Id. at 2483. Further on, Justice Kennedy reasons that the Framers did not, and could not, anticipate all the complexities of a rich conception of liberty as secured by the general terms of the Due Process Clauses of the Fifth and Fourteenth Amendments. Instead, later generations would come to understand its true nature and that over time people could draw from that liberty right "in their own search for greater freedom." Id. at 2484. These passages imply that the liberty Kennedy reaches for in Laurence is a narrower concept than freedom.

What does he mean by differentiating freedom from liberty? It is worth noting that of languages of European origin, both ancient and modern, only English contains both "freedom" and "liberty." Hanna Fenichel Pitkin, Are Freedom and Liberty Twins?, 16 Pol. Theory 523, 523 (1988). German jurists are able to turn only to freiheit, and the French have no choice but to bundle fraternité and egalité with liberté. Political philosophers typically treat liberty and freedom as virtually interchangeable concepts that may be differentiated from one another semantically but not substantively. Id. Pitkin notes that freedom is more commonly used in prepositional phrases, while liberty is more likely to occur in the plural. Id. at 539. In an attempt to discern whether there are, in fact, deeper substantive differences between the two concepts beyond those of common usage, Hanna Pitkin argues that in general

freedom is more likely to be holistic, to mean a total condition or state of being, while liberty is more likely to be plural and piecemeal. Second, freedom is more likely than liberty to be something psychic, inner, and integral to the self . . . . [F]reedom includes unobstructed space and movement, even of inanimate objects, as liberty does not.

ld. at 542 .

I3. Lawrence, I23 S. Ct. at 2475.

14. 505 U.S. 833, 851 (1992).

15. Lawrence, 123 S. Ct. at 2475. 
The cabining of Lawrence's liberty is accomplished through its geographization. Recall that while "[f]reedom extends beyond spatial bounds," the liberty interest at stake is one that is tethered to the domestic private. Repeatedly, Justice Kennedy territorializes the right at stake as a liberty to engage in certain conduct in private: "We conclude the case should be resolved by determining whether the petitioners were free as adults to engage in the private conduct in the exercise of their liberty under the Due Process Clause of the Fourteenth Amendment . . .."16 Precedent in the last half century demonstrates

an emerging awareness that liberty gives substantial protection to adult persons in deciding how to conduct their private lives in matters pertaining to sex. . . . The petitioners are entitled to respect for their private lives. The State cannot demean their existence or control their destiny by making their private sexual conduct a crime. . . . The Texas statute furthers no legitimate state interest which can justify its intrusion in to the personal and private life of the individual. ${ }^{17}$

The privatization of the liberty right in Lawrence is interesting on a number of counts. As an initial matter, the Court chose to lodge the right at stake in liberty and not privacy. Surely there were plausible privacy arguments that could have been made to demonstrate the unconstitutionality of the Texas statute; indeed, one of the questions on which the Court granted certiorari was whether the Texas statute violated the rights to liberty and privacy. ${ }^{18}$ To be sure, the Court relied on some of its most fundamental privacy cases in finding a violation of a liberty interest in Lawrence. ${ }^{19}$ But even the Court's privacy jurisprudence has evolved from addressing the disclosure of matters of private concern ${ }^{20}$ and governmental intrusion into private spaces ${ }^{21}$ to a less situated or territorial notion of

16. Id. at 2476.

17. Id. at $2480-84$.

18. "Whether Petitioners' criminal convictions for adult consensual sexual intimacy in the home violate their vital interests in liberty and privacy protected by the Due Process Clause of the Fourteenth Amendment?" Brief for Petitioners at i, Lawrence, $123 \mathrm{~S}$. C.t. (No. 02-102). Indeed, the decision in Bowers was based, in part, in a rejection of "a right of privacy that extends to homosexual sodomy." See Bowers v. Hardwick, 478 U.S. 186, 190-91 (1986). The petitioners in Laurence and virtually every party that submitted an amicus brief in their support argued for reversal on privacy grounds. See, e.g., Brief of the American Bar Association as Amicus Curiae in Support of Petitioners at 5, Lawrence, $123 \mathrm{~S}$. Ct. (No. 02-102); Amicus Brief of Human Rights Campaign et al. in Support of Petitioners at 1-2, Lawrence, $123 \mathrm{~S}$. Ct. (No. 10-102). 1 will return to privacy as a ground for securing sexual rights. See infra notes 38-49 and accompanying text.

19. See Lawrence, 123 S. Ct. at 2476-77 (citing Griswold v. Connecticut, 381 U.S. 479 (1965), and Eisenstadt v. Baird, 405 U.S. 438 (1972)).

20. See, e.g., Whalen v. Roe, 429 U.S. 589, 598-600 (1977) (recognizing the right of "nondisclosure of private information" as constitutionally protected in the Court's "zone of privacy" jurisprudence).

21. See, e.g., Griswold, 381 U.S. at $485-86$ (noting that marriage enjoys a "right of privacy older than the Bill of Rights" in striking down a state statute outlawing the use of contraceptives by married persons). 
protecting a zone of personal autonomy and decisional privacy. ${ }^{22}$ Early privacy law was both relational, in the sense of applying to the marital relationship, and spatially domesticated, in the sense of pertaining to activities in the most private confines of the home. ${ }^{23}$ But the Court's privacy jurisprudence has evolved such that it is now concerned less with institutions like marriage and the home and more with personal independence. Lawrence's privatized liberty appears to resuscitate a very early, more limited, and more institutional version of the privacy right. To invalidate the Texas sodomy law, Justice Kennedy brings to bear a form of liberty that favors "respect for [gay men's] private lives," 24 over " the right to define one's own concept of existence, of meaning, of the universe, and of the mystery of human life." "25

\section{Situating Lawrence's Liberty in a Global Gay Rights Context}

At the outset of this Commentary, 1 suggested that we consider Lawrence in light of the differences between freedom, rights, and the political. The Court chose to invalidate the Texas sodomy law with a particular rights analysis-that of privatized liberty. The Court could have, however, chosen a genus of rights other than liberty on which to rest its holding. 1t is worth asking whether a different kind of right might have opened up different possibilities for future legal and political action.

South Africa's experience with similar statutes outlawing sodomy provides a useful comparison. In I998, the South African Constitutional Court found that the 1957 Sexual Offenses Act, the national law criminalizing sodomy, violated the constitution on three theories: equality, dignity, and privacy. ${ }^{26}$ The guarantee of equality in the South African Constitution goes beyond the rather formalist and proceduralist version embodied in U.S. constitutional jurisprudence to include a substantive component: "Neither s[ection] 8 of the interim Constitution nor s[ection] 9 of the 1996 Constitution envisages a passive or purely negative

22. In many respects, Eisenstadt marked the beginning of this shift. In that case, the Court extended the privacy right enjoyed in the marital context to individuals, stating: "If the right of privacy means anything, it is the right of the individual, married or single, to be free from unwarranted governmental intrusion into matters so fundamentally affecting a person as the decision whether to bear or beget a child." 405 U.S. at 453.

23. "The Court [in Griswold] described the protected interest as a right to privacy and placed emphasis on the marriage relation and the protected space of the marital bedroom." Lawrence, $123 \mathrm{~S}$. Ct. at 2477 . For a thoughtful discussion of the forms of privacy advanced by the Supreme Court, see Kendall Thomas, Beyond the Privacy Principle, 92 Colum. L. Rev. 1431 (1992).

24. Lawrence, 123 S. Ct. at 2484.

25. Id. at 2481 (quoting Planned Parenthood v. Casey, 505 U.S. 833, 851 (1992)).

26. See Nat'l Coalition for Gay \& Lesbian Equal. v. Minister of Justice, 1999 (1) SALR 6 (CC) II 14-26, 27-39. Justice Ackermann, writing for the court, expressed a preference for the first two grounds upon which the Act was found unconstitutional, but noted that the "case illustrates how, in particular circumstances, the rights of equality and dignity are closely related, as are the rights of dignity and privacy." Id. I 30. 
concept of equality; quite the contrary." 27 The court recognized "that discrimination against people who are members of disfavoured groups can lead to patterns of group disadvantage and harm. Such discrimination is unfair: it builds and entrenches inequality amongst different groups in our society." 28 Clearly the South African Constitutional Court's invocation of an equality right in National Coalition for Gay and Lesbian Equality invites a more structural analysis of the effects of state-sponsored heterosexism than would the strict formalism of U.S. equality jurisprudence.

Of more relevance is the court's reasoning about dignity: "[T]he constitutional protection of dignity requires us to acknowledge the value and worth of all individuals as members of our society." 29 Focusing less on the legal fact of regulating private sexual conduct, Justice Ackermann turns the court's attention to the structural effects of rendering gay men a class of outlaws. "Gay men are a permanent minority in society and have suffered in the past from patterns of disadvantage. The impact is severe, affecting the dignity, personhood and identity of gay men at a deep level."30 Justice Ackermann goes on to recognize the stigmatic and other symbolic penalties created by the Sexual Offenses Act: "There can be no doubt that the existence of a law which punishes a form of sexual expression for gay men degrades and devalues gay men in our broader society." 31 In Lawrence, Justice Kennedy also recognizes the stigmatic consequences of sodomy laws, but does so in a manner far more narrow than Justice Ackermann in National Coalition. Kennedy notes the stigma caused by criminal convictions, while Ackermann ties the stigma to the mere existence of sodomy laws, whether or not they are being enforced and convictions are obtained on their behalf. As Nan Hunter notes, "[s]odomy laws have been most frequently enforced indirectly, not directly, by the denial of custody or other parental rights to gay parents or by exclusions from certain jobs ... even though the litigants had never been convicted of illegal conduct." 32

While Justice Ackermann found the Sexual Offenses Act unconstitutional on equality, dignity, and privacy grounds, he clearly found the privacy argument the least compelling of the three. First, in discussing the privacy claim, he begins by acknowledging both the drawbacks and limitations of the privacy argument as it tends to reinforce the idea that sodomy is something to be shamefully hidden in the confines of the private bed-

27. Id. I 16.

28. Id. (quoting Brink v. Kitshoff NO, 1996 (4) SALR 197 (CC) Il 42).

29. Id. II 28.

30. Id. I 26 (a). Note that in declaring invalid the omission of "sexual orientation" as a ground for illegal discrimination in an Albertan statute, the Canadian Supreme Court invoked a theory of dignity grounded in the constitution (Charter) as well. See Vriend v. Alberta, [1998] S.C.R. 493, II 104.

31. Nat'l Coalition, 1999 (1) SALR If 28.

32. Hunter, supra note 2 (manuscript at 1131). 
room. ${ }^{33}$ Second, and more importantly, Justice Ackermann concludes his long treatment of the various grounds upon which the Sexual Offenses Act violated the South African Constitution by offering a hypothetical that he believes manifestly demonstrates the absurdly discriminatory purpose and impact of the sodomy law:

A gay couple attend [sic] a social gathering attended by gay, lesbian and heterosexual couples. The gay man, in the presence of other guests, kisses his gay partner on the mouth in a way "calculated to stimulate" both his and his partner's "sexual passion" and to give both "sexual gratification". They do no more. A lesbian and a heterosexual couple do exactly the same. The gay couple are [sic] guilty of an offence. The lesbian and heterosexual couples are not. ${ }^{34}$

What is remarkable about this hypothetical is the degree to which its absurdity does not depend on a conception of privacy. The kiss is in public, in front of an audience, and is explicitly erotic in nature. 1t is the disparate legal treatment of similarly situated kissers that strikes Justice Ackermann as absurd and unfair, not the location in which the same-sex kissing takes place.

By reading the dignity right in light of an equality right, the court in National Coalition was able to articulate the constitutional infirmity of the Sexual Offenses Act in a way that differs substantially from what the Court accomplished in Lawrence. While Justice Ackermann foregrounds equality and dignity and backgrounds privacy in his opinion, Justice Kennedy foregrounds privacy, backgrounds dignity, and rejects the equality argument altogether. With a change of emphasis, Justice Kennedy could have made Lawrence turn on a recognition of how sodomy laws inflict a badge of inferiority, indeed a badge of the closet, ${ }^{35}$ on gay men and lesbians.

The course of South African constitutional jurisprudence since $\mathrm{Na}$ tional Coalition teaches that the privatized liberty of Lawrence is indeed something about which concern is appropriate. In Jordan $v$. State, ${ }^{36}$ decided four years after National Coalition, the South African Constitutional Court was confronted with a constitutional challenge to a statute that criminalized prostitution on the ground that it interfered with economic activity, violated the privacy rights of sex workers, and discriminated against sex workers as compared with their customers. The sex workers in the case relied upon National Coalition in arguing that the statute inflicted stigma and social opprobrium on sex workers in ways quite similar to the dignity harm inflicted upon gay men by the Sexual Offenses Act. ${ }^{37}$ The Constitutional Court found the sodomy analogy inapposite and refused to extend the equality or dignity analysis of National Coalition to sex

33. Nat'l Coalition, 1999 (1) SALR II 29.

34. Id. II 75. closet.

35. Conversations with Jeremy WaIdron suggested the concept of a badge of the

36. 2002 (11) BCLR 1117 (CC).

37. Id. I 27. 
workers, preferring instead to analyze the case under a privacy theory: "[T] he prostitute invites the public generally to come and engage in unlawful conduct in private"; 38 therefore, the activity at interest did not implicate privacy. Given the commercial nature of the sex and the fact that the appellants were not intimately related to the men with whom they had sex, the dignity and privacy concerns that animated the sodomy case were inapplicable. Thus we see how the privacy argument that had been backgrounded in National Coalition is foregrounded in Jordan and pressed into service to distinguish the kind of sexual rights claim asserted by sex workers from that asserted by respectable gay men and lesbians.

To a troubling degree, the privacy dimension of Jordan and the privatized liberty of Laurence leave lower courts free to cabin protection of, and thus interpret, nonnormative sexualities in ways similar to Stanley $v$. Georgia, ${ }^{39}$ in which the Court tolerated obscenity at the price of demeaning it, characterizing it as "a base thing that should nonetheless be tolerated so long as it takes place in private." 40 The work done by the public/ private distinction in Jordan may portend a Stanley-like treatment of privacy and privatized liberty rights for nonnormative sexualities: Unless they are expressed in respectable private contexts, they may not seek refuge in the Constitution. As the Court in Bowers pointed out, "Stanley did protect conduct that would not have been protected outside the home, and it partially prevented the enforcement of state obscenity laws . . ."41 Justice Kennedy's opinion in Lawrence not only fails to repudiate this part of Bowers, but Kennedy's privatized liberty leaves a wide range of homosexual and heterosexual behaviors and "lifestyles" 42 subject to criminalization. 1t is hard to imagine Justice Kennedy using as an example the public display of explicitly erotic same sex behavior to illustrate the right at issue in Laurence-recall Justice Ackermann's gay men kissing at a party. Indeed, he could not, given how he re-closets Lawrence and Garner's constitutional right in the hidden domain of the private.

Jordan suggests another reason to be wary of the narrow privatized liberty right announced in Lawrence. Recall that Justice Kennedy takes it as given that the sex between John Lawrence and Tyron Garner took place within the context of a relationship. With respect to the right to make decisions about intimate affiliations in private settings, Justice Kennedy notes that " $[\mathrm{p}]$ ersons in a homosexual relationship may seek autonomy for these purposes, just as heterosexual persons do," 43 and that the statutes at issue in Laurence and in Bowers "seek to control a personal rela-

38. Id. I 28.

39. 394 U.S. 557 (1969).

40. Michael J. Sandel, Moral Argument and Liberal Toleration: Abortion and Homosexuality, 77 Cal. L. Rev. 521, 537 (1989).

41. Bowers v. Hardwick, 478 U.S. 186, 195 (1986).

42. See Lawrence v. Texas, 123 S. Ct. 2472, 2484 (2003) ("The case does involve two adults who, with full and mutual consent from each other, engaged in sexual practices common to a homosexual lifestyle." (emphasis added)).

43. 1d. at 2482 . 
tionship that, whether or not entitled to formal recognition in the law, is within the liberty of persons to choose without being punished as criminals." 44 Note that the analogy here is between persons in a homosexual relationship and heterosexual persons. ${ }^{45}$ Thus, the issue in Lawrence, as well as in Bowers, was not the right to engage in certain sexual conduct - that, says Kennedy, would be demeaning to John Lawrence and Tyron Garner. They would be disgraced just as a married couple would be if the claim were made that "marriage is simply about the right to have sexual intercourse." 46 Kennedy writes that "[sexual conduct] can be but one element in a personal bond that is more enduring." 47 More enduring than what? Than sex?

In two paragraphs, Justice Kennedy does a thorough job of domesticating John Lawrence and Tyron Garner-Lawrence an older white man, Garner a younger black man, who for all we know from the opinion, might have just been tricking with each other. Did they even know each other's name at the point police entered Lawrence's apartment? Did they plan on seeing each other again? None of these facts is in the record, none of the briefing in the case indicated that they were in a relationship. Nevertheless, the Court took it as given that Lawrence and Garner were in a relationship, and the fact of that relationship does important normative work in the opinion. Remember, sex is but one element in a personal bond that is more enduring.

Just as the Court's earlier Bowers decision and the military's "don't ask, don't tell" 48 policy overdetermined gay men and lesbians in sexual terms, we now celebrate a victory that at its heart underdetermines, if not writes out entirely, their sexuality. Previously, when courts considered the legal status of gay men, they approached the specter of homosexual sex with a horror ordinarily reserved for incest cases. ${ }^{49}$ Now gay men are portrayed as domesticated creatures, settling down into marital-like relationships in which they can both cultivate and nurture desires for exclusivity, fidelity, and longevity in place of other more explicitly erotic

44. Id. at 2478.

45. My colleague Kendall Thomas has read the asymmetry of this language in Lawrence through a lens that foregrounds its heteronormativity. See Kendall Thomas, Remarks for AALS Panel on Lawrence v. Texas (Jan. 4, 2004) (on file with the Columbia Law Review).

46. Lawrence, 123 S. Ct. at 2478.

47. Id.

48. National Defense Authorization Act of 1993, 10 U.S.C. $\S 654$ (2000).

49. Judith Butler uses Sophocles' Antigone to explore the ways in which alternative kinship arrangements tend to provoke psychic revulsion or horror in the psychically "normal" reader:

Consider that the horror of incest, the moral revulsion it compels in some, is not that far afield from the same horror and revulsion felt toward lesbian and gay sex .... The various modes in which the oedipal mandate fails to produce normative family all risk entering into the metonymy of that moralized sexual horror that is perhaps most fundamentally associated with incest.

Judith P. Butler, Antigone's Claim: Kinship Between Life and Death 71 (2000). 
desires. "The instant case involves liberty of the person both in its spatial and more transcendent dimensions," writes Justice Kennedy. ${ }^{50}$ We come to learn later in the opinion that by "spatial" he means private, and by "transcendent" he means to refer to relationship-based intimacy. The price of the victory in Lawrence has been to trade sexuality for domesticity-a high price indeed, and a difficult spot from which to build a politics of sexuality. As Teemu Ruskola has observed, Kennedy's opinion "leaves little or no justification for protecting less-than-transcendental sex that is not part of an on-going relationship." 51

Again, the sexuality jurisprudence of another jurisdiction is instructive with respect to the horizons Lawrence at once opens up and forecloses. In a 1981 case, Dudgeon v. United Kingdom, ${ }^{52}$ the European Court of Human Rights (ECHR) ruled that Northern lreland's sodomy law violated Article 8 of the European Convention on Human Rights ${ }^{53}$ to the extent that it amounted to "an unjustified interference with [Dudgeon's] right to respect for his private life." ${ }^{4}$ Fifteen years later, in the Spanner case, the ECHR refused to extend the ruling in Dudgeon to invalidate the criminal conviction of three adult men who had engaged in consensual sadomasochistic sex in private. ${ }^{55}$ Although the activities the men engaged in "were conducted in private for no apparent purpose other than the achievement of sexual gratification," 56 the court ruled that the law of assault could not admit adults' consent to sadomasochistic sex. In finding that the privacy provisions of Article 8 of the European Convention on Human Rights were not violated by the applicants' convictions, the court was forced to distinguish Dudgeon. So too, the court had to contend with an earlier British case, $R$. v. Wilson, ${ }^{57}$ in which the Court of Appeal reversed the assault conviction of a man who had, with his wife's consent, branded his initials with a hot knife on her buttocks, reasoning that "Mrs. Wilson not only consented to that which the appellant did, she instigated

50. Laurence, 123 S. Ct. at 2474.

51. Ruskola, supra note 5 (manuscript at 7 ).

52. 45 Eur. Ct. H.R. (ser. B) at 1 (1981).

53.

(1) Everyone has the right to respect for his private and family life, his home and his correspondence.

(2) There shall be no interference by a public authority with the exercise of this right except such as is in accordance with the law and is necessary in a democratic society in the interests of national security, public safety or the economic well-being of the country, for the prevention of disorder or crime, for the protection of health and morals, or for the protection of the rights and freedoms of others.

Convention for the Protection of Human Rights and Fundamental Freedoms, Nov. 4, 1950, art.8, 213 U.N.T.S. 221, 230.

54. Dudgeon, 45 Eur. Ct. H.R. at 25.

55. Laskey v. United Kingdom, 24 Eur. H.R. Rep. 39 (1997). The case is commonly referred to as the Spanner case because the Manchester Police arrested the defendants in a raid as part of "Operation Spanner."

56. Id. at 41-42.

57. 1997 Q.B. 47 (Eng. C.A.). 
it. There was no aggressive intent on the part of the appellant."58 The Spanner court found Wilson inapplicable: "Consensual activity between husband and wife, in the privacy of the matrimonial home, is not, in our judgment, a proper matter for criminal investigation, let alone criminal prosecution."59 In the end, it did not matter to the court that the Spanner defendants' activities took place in private ${ }^{60}$ or that all of the conduct was consensual. Rather, what rendered the conduct regulable was the fact that the participants either were or could have been physically injured. Notwithstanding the important value placed on protecting private life, the court reasoned that state interference with private activities could be justified on the ground of protecting health. By contrast, without much in the way of explanation, the ECHR concluded that neither health nor morals were at stake when Mr. Wilson branded his initials on Mrs. Wilson's buttocks.

Three years later, the ECHR had to grapple once more with the legal status of nonnormative sexual behaviors when British police executed a search warrant in the home of a "practicing homosexual" and seized, among other things, video tapes showing him engaging in sexual activities with up to four other adult men in his home. ${ }^{61}$ Based on the acts depicted in the video tapes, the man, A.D.T., was charged with gross indecency between men under the 1956 Sexual Offenses Act. A.D.T. claimed that his privacy rights had been abridged and relied, in siguificant part, on the ECHR's earlier Dudgeon decision. Finding no threat to public health or likelihood that the videos would make their way into the public domain, the court concluded that "the activities were therefore genuinely 'private'" 62 and that the prosecution violated A.D.T.'s privacy rights. In A.D.T., the ECHR chose not to rest its privacy holding on the decisional autonomy norm they relied upon in Wilson, for that would have created problems for their earlier Spanner decision. lnstead they reached for a spatial conception of privacy, excusing the nonnormative sexual practices that A.D.T. indulged in as unlikely to gain a public audience.

The lesson of the ECHR's recent sexual privacy jurisprudence is that rather raunchy forms of sex can be insulated from governmental regulation if they take place within a marriage or, absent a marriage or other sanctioned relationship, if they in no way threaten to seep into public view. If cases like these were to come before the United States Supreme Court now, of the three, a case with A.D.T.-like facts would likely come out differently. The sex at issue in A.D.T. was not an expression of an enduring bond, and it did not take place in the context of a relationship.

58. Id. at 50.

59. Laskey, 24 Eur. H.R. Rep. at 46 (quoting Wilson, 1997 Q.B. at 50).

60 . Id. (" $[1] \mathrm{n}$ our judgement, it is immaterial whether the act occurs in private or in public." (quoting Attorney-General's Reference (No. 6 of 1980), [1981] Q.B. 715, 719 (Eng. C.A.))).

61. A.D.T. v. United Kingdom, 3I Eur. H.R. Rep. 803 (2001).

62. Id. at 811. 
Indeed, there was nothing about it that evokes the warm, fuzzy, domesticated backdrop of Lawrence. It was just sex. Laurence, most likely, would provide those men little comfort.

Having said all this, let me be clear about one thing: Decriminalization of sodomy is no small thing, and 1 do not seek to minimize the significance of this aspect of Lawrence. Rather, my concern is with what the decision in Lawrence opens up and shuts down for nonnormative sexual identities-where does it take us next and what arguments are enabled and foreclosed by Lawrence's reasoning? Lawrence puts an end to the interpellation of gay male and lesbian couples as criminals based upon their private sexual conduct. But what kind of legal and political subjectivity does Lawrence announce for us?

\section{LaWrenCE's Liberty and Gay Rights Politics}

To ask the question in this way is to recognize that decriminalization does not necessarily mobilize any particular ethical projects, or for that matter, any ethics at all. Rather, decriminalization merely disables a form of public regulation of private adult activity. Indeed, it neither sanctions nor suggests any alternative form of legitimization. So too, it does not render viable any particular kind of sexual politics or political legibility. ${ }^{63}$ Without more, Lawrence-like decriminalization merely signals a public tolerance of the behavior, so long as it takes place in private and between two consenting adults in a relationship.

If only these concerns about the limited utility of Lawrence were an overreaction on my part. But it took no time for lower courts to read Lawrence in the limited terms I have suggested. The day after the Su-

63. By political legibility, I mean the ways in which subjects become visible and are rendered viable as citizens, as parties who can make demands on the state, and are otherwise regarded as both making up and speaking to a range of publics. For an elaboration of the notion of "publics," see Michael Warner, Publics and Counterpublics (2002), at http://www.uchicago.edu/research/jnl-pub-cult/backissues/pc36/warner.html (on file with the Columbia Law Review). As Warner sketches it out:

The public is a kind of social totality. Its most common sense is that of the people in general. It might be the people organized as the nation, the commonwealth, the city, the state, or some other community. It might be very general, as in Christendom or humanity. But in each case the public, as a people, is thought to include everyone within the field in question. This sense of totality is brought out in speaking of the public, even thougb to speak of a national public implies that others exist; there must be as many publics as polities, but whenever one is addressed as the public, the others are assumed not to matter.

A public can also be a second thing: a concrete audience, a crowd witnessing itself in visible space, as with a theatrical public. Such a public also has a sense of totality, bounded by the event or by the shared physical space. A performer on stage knows where her public is, how big it is, where its boundaries are, and what the time of its common existence is. A crowd at a sports event, a concert, or a riot might be a bit blurrier around the edges, but still knows itself by knowing where ld. and when it is assembled in common visibility and common action. 
preme Court issued its decision in Lawrence, it vacated a Kansas appellate court decision, Limon v. Kansas, and sent it back to the Kansas Court of Appeals for further consideration. ${ }^{64}$ Matthew Limon, an eighteen-yearold man, ${ }^{65}$ had been convicted of having had oral sex one time with a fourteen-year old boy in a school for developmentally disabled children that they both attended. Kansas law punishes homosexual sex with a minor much more harshly than heterosexual sex with a minor. ${ }^{66}$ Indeed, Limon received a sentence of more than seventeen years, thirteen times longer than he would have received if he had had sex with an underage female. The differential penalties based on the sexual identity of the defendant seemed like a prime target for the newly minted Lawrence decision.

Not so, said the Kansas Court of Appeals on remand. The major premise of the Lawrence decision, writes the Kansas court, is that "[a]11 adults may legally engage in private consensual sexual practices common to a homosexual lifestyle." 67 Thus, Lawrence had no application to the Kansas statute as it did not involve adults. What is more, the court notes, the preference the statute gives to different-sex sexual activity is justified on the grounds that the state has no interest in protecting same-sex sex, while it has a fundamental interest in heterosexual sex: "Throughout history, governments have extolled the virtues of procreation as a way to furnish new workers, soldiers, and other useful members of society. The survival of society requires a continuous replenishment of its members. ... [S] exual acts between same-sex couples do not lead to procreation on their own." 68 So too, sexual contact between persons of different sexes can lead to unwanted pregnancies, thus " $[t]$ he legislature could well have concluded that incarcerating the young adult parent for a long period would be counterproductive to the requirement that a parent has a duty to provide support to his or her minor child." 69

64. Limon v. Kansas, 123 S. Ct. 2638 (2003).

65. The act took place a week after his eighteenth birthday. State v. Limon, 83 P.3d 229, 243 (Kan. Ct. App. 2004) (Pierron, J., dissenting).

66. Kansas has a so-called "Romeo and Juliet" law that makes the penalty for statutory rape less severe when the case involves two teenagers. The "Romeo and Juliet" law reads:

Unlawful voluntary sexual relations is engaging in voluntary: (1) sexual intercourse; (2) sodomy; or (3) lewd fondling or touching with a child who is 14 years of age but less than 16 years of age and the offender is less than 19 years of age and less than four years of age older than the child and the child and the offender are the only parties involved and are members of the opposite sex.

Kan. Stat. Ann. \$21-3522(a) (2003) (emphasis added). Limon was sentenced to 206 months in prison followed by sixty additional months of postrelease supervision, and he must register as a sex offender. Had he had sex with a female, he would have received a fifteen-month sentence. Limon, 83 P.3d at 243 (Pierron, J., dissenting).

67. Limon, 83 P.3d at 234.

68. Id. at 237.

69. Id. At least in Kansas, Lawrence did nothing to unsettle Bowers's declaration that there is no "connection between family, marriage, or procreation on the one hand and homosexual activity on the other." Bowers v. Hardwick, 478 U.S. 186, 191 (1986). 
Limon makes clear how some lower courts may understand Lawrence to impose absolutely no check on the legal enforcement of heteronormative preferences. Lawrence has no application to sex unrelated to childbearing, sex that might lead to childrearing obligations, and sex that involves a minor (even if that sex would be treated far less harshly if it had taken place between persons of different sexes). Indeed, Lawrence also offers little to those who seek to invalidate fornication or adultery laws. ${ }^{70}$ In this respect, the limitations of Lawrence's domesticated liberty should be of equal concern to those who seek to engage in nonnormative heterosexual behavior.

There is no denying that rights in general, and liberty in particular, are something we cannot not want, to borrow a concept from Gayatri Spivak. ${ }^{71}$ But rights, particularly in the form articulated in Lawrence, cannot exhaust our political projects. Lawrence recognizes, in a manner far more robust than Romer $v$. Evans, ${ }^{72}$ that homosexuals are rights-bearing subjects. But the political agenda leveraged by that recognition does not exceed honor of the domesticated private. The most likely project to be launched from this conception of subjectivity is, of course, marriage. ${ }^{73}$ And, of course, that's exactly what Lawrence has unleashed. Less than six months after the Supreme Court issued the Lawrence decision, the Massachusetts Supreme Judicial Court found that Massachusetts's refusal to license same-sex marriage was unconstitutional, and in so finding it relied very heavily upon Laurence. $^{74}$ For a short period thereafter, gay and lesbian couples overwhelmed public officials in a handful of cities demanding marriage licenses. The relevant officials in San Francisco, New Paltz, and a couple of other jurisdictions accommodated those demands and married thousands of gay and lesbian couples. As such, the subjects of gay and lesbian political organizing at this moment have become same-

70. None of the Supreme Court's privacy or liberty jurisprudence has served as the basis upon which to invalidate fornication laws. See State v. Lutz, 272 A.2d 753 (N.J. 1971); Robert A. Brazener, Annotation, Validity of Statute Making Adultery and Fornication Criminal Offenses, 41 A.L.R.3d 1338 (1972). Nan Hunter reads the opinion differently, insofar as she understands it to delink sex and marriage. See Hunter, supra note 2 (manuscript at 1110). In this regard, Hunter does not understand the Court to be domesticating homosex in the ways that Ruskola and I do.

71. Gayatri Chakravorty Spivak, Outside in the Teaching Machine 46 (1993).

72. 517 U.S. 620 (1996).

73. It is worth noting that the use of marriage-related legal reforms launched by Laurence to aid efforts to legalize same-sex marriage have, so far, had mixed results. In Goodridge v. Department of Public Health, 798 N.E.2d 941, 948 (Mass. 2003), the Massachusetts Supreme Judicial Court relied, in part, on Laurence in holding that the Commonwealth's prohibition of same-sex marriages violated the Massachusetts Constitution, whereas Lawrence was of no help in a challenge to marriage laws in Arizona. Standhardt v. Superior Court ex rel. County of Maricopa, 77 P.3d 451, 456-58 (Ariz. Ct. App. 2003).

74. The court's opinion begins with three citations to Lawrence. See Goodridge, 798 N.E.2d at 948 . 
sex couples, not persons who seek nonnormative kinship formations or individuals who engage in nonnormative sex.

But it is wrong to understand the fight for gay marriage as a fight for sexual freedom or, for that matter, relationship-based freedom. Marriage is not a freedom. Rather, it is a power understood in Hohfeldian terms, and as a power it is the less interesting pouvoir, not puissance. The states have created a civil status called marriage, just as the states have created voting criteria and rights to inheritance. One either is or is not the kind of person to whom the state has given the power to enter into a civil marriage, to exercise the vote, or to inherit property. One has the power, not the freedom, to marry, to vote, and to inherit property. Borrowing Hohfeld's notions of legal liberty and legal liability, Carl Wellman has written: "[W]hat the same-sex couple lacks is not a legal liberty of marrying one another [in a state that does not allow same-sex marriage] but a legal liability of being married to each other." 75 The state creates rules and conventions that govern these sorts of powers, and the denial of the ability to participate does not trammel upon a fundamental freedom, understood in traditional liberal terms. To the extent that same-sex couples are denied the ability to marry, that denial best surfaces in law as a problem of equality, of indefensible differential treatment, but not as a matter of freedom. ${ }^{76}$ Refusing to adopt the rhetoric of freedom, Judith Butler has more aptly articulated what is at stake in the movement for gay marriage: "The petition for marriage rights seeks to solicit state recognition for nonheterosexual unions, and so configures the state as withholding an entitlement that it really should distribute in a nondiscriminatory way, regardless of sexual orientation." 77

1 fear that Lawrence and the gay rights organizing that has taken place in and around it have created a path dependency that privileges privatized and domesticated rights and legal liabilities, while, rendering less viable projects that advance nonnormative notions of kinship, intimacy, and sexuality. Judith Butler has voiced a similar concern with respect to the gravitational pull of same-sex marriage, to the extent that it fails to "attend to the foreclosure of the possible that takes place when, from the urgency to stake a political claim, one naturalizes the options

75. Carl Wellman, A Theory of Rights: Persons Under Laws, Institutions, and Morals 87 (1985).

76. Nevertheless, the same-sex marriage movement has termed its cause and its principal organizations working on the issue "freedom to marry." See, e.g., California Freedom to Marry Coalition, at http://www.civilmarriage.org (last visited Apr. 12, 2004) (on file with the Columbia Law Review); Freedom to Marry, at http://www.freedomtomarry. org (last visited Apr. 12, 2004) (on file with the Columbia Law Review); Freedom to Marry Coalition of Massachusetts, at http://www.equalmarriage.org (last visited Apr. 12, 2004) (on file with the Columbia Law Review); Vermont Freedom to Marry Task Force, at http:// www.vtfreetomarry.org (last visited Apr. 12, 2004) (on file with the Columbia Law Review).

77. Judith Butler, Is Kinship Always Already Heterosexual?, in Left Legalism/Left Critique 229, 230-31 (Wendy Brown \& Janet Halley eds., 2002). 
that figure most legibly within the sexual field."78 So too, Lauren Berlant has challenged us to think critically about "why, when there are so many people, only one plot counts as 'life' (first comes love, then ...)? Those who don't or can't find their way into that story-the queers, the single, the something else-can become so easily unimaginable, even often to themselves." 79

It is not only gay men and lesbians who have a stake in exploring why only one plot counts, why a successful adult life requires life-long commitment, and through what means our desires for intimacy and domesticity are cultivated to the point that alternatives seem like failure, dysfunction, or are unthinkable. "Everybody wants love. Everybody wants it to last forever," declared Susan Ager, a lesbian columnist for the Detroit Free Press. ${ }^{80}$ Lawrence and the political action that has followed in its wake have contributed to a notion that everyone wants the same thing, and that that thing is unproblematic. Elizabeth Povinelli has challenged us to question the institutional forces that have normalized certain forms of kinship, such that it is taken for granted that healthy self-elaboration and personal transcendence must take place in the context of an intimate, domestic couple. ${ }^{81}$ Nevertheless, the gay and lesbian movement has become captive to leaders who advance the view that there

is no other way for gay people to be fully equal to non-gay people-both in the eyes of the law, and in the eyes of the larger community-than to participate in the same legal institution using the same language. . . Any alternative to marriage is not marriage. Anything less, is less than equal! ${ }^{12}$

Laurence is a slam-dunk victory for a politics that is exclusively devoted to creating safe zones for homo- and hetero-sex/intimacy, while at the same time rendering all other zones more dangerous for nonnormative sex. It can be used to float political projects that render certain normative heterosexual couples as its primary reference points and ethical paradigms. Lawrence and the ethics from which it evolved do little to open up new forms of public and private sexual intelligibility that are not always already domestinormative. ${ }^{83}$ The landscape post-Lawrence is not one that makes formal legal distinctions between heterosexual and ho-

78. Id. at 235 .

79. Lauren Berlant, Intimacy: A Special Issue, 24 Critical Inquiry 281, 286 (1998).

80. Susan Ager, The Mayor Shows Heart in San Francisco, Detroit Free Press, Feb. 17, 2004, at 1E, available at http://www.freep.com/features/living/ager17_20040217.htm (on file with the Columbia Law Review).

81. Elizabeth A. Povinelli, Notes on Gridlock: Genealogy, Intimacy, Sexuality, 14 Pub. Culture 215, 231 (2002).

82. Marriage Equality California \& Lambda Legal Defense and Education Fund, Roadmap to Equality: A Freedom to Marry Educational Guide 15 (2002), available at http://www.lambdalegal.org/binary-data/LAMBDA_PDF/pdf/122.pdf (on file with the Columbia Law Review) (emphasis in original).

83. I use this rather awkward neologism because "heteronormative" no longer describes the preferences that punish, exile, or erase persons who fail to emulate a marital model. 
mosexual practices, but rather one that likely renders different legal treatment to those who express their sexuality in domesticated ways and those who don't-regardless of orientation. The world post-Laurence remains invested in forms of social membership and, indeed, citizenship that are structurally identified with domesticated heterosexual marriage and intimacy. Laurence offers us no tools to investigate "kinds of intimacy [and sex] that bear no necessary relation to domestic space, to kinship, to the couple form, to property, or to the nation." 84 In this regard, the opinion's implications are at once modest and quite broad in scope. The legal program that is most easily suggested by Lawrence is one undertaken by adult gay couples who seek recognition for their relationships and whose sexuality is not merely backgrounded, but closeted behind the closed doors of the bedroom. This is a project devoted to celebrating our relationships; it is not a project of sexual rights or the politics of sexuality. Indeed, against this framing of the "gay agenda," the heterosexual reproductive rights cases start looking pretty darn radical. In this sense, overreliance on Lawrence risks domesticating rights, sex, and politics, and charting us down a path of domestinormative sexual citizenship. The political subjects it predetermines are husbands and wives, and the legal projects it maps out do not extend beyond gay marriage.

The lessons of the black civil rights movement instruct that political movements should exercise caution in overidentifying their objectives with the terms and scope of advances made in the legal arena. While there is some truth to the celebration of Lawrence as the gay community's Brown, one would hope that this is not so in every respect. The legal and rhetorical moves that the Brown Court deemed necessary to reverse Plessy v. Ferguson were quickly revealed as ill-equipped to provide prospective racial justice in any systematic way, and indeed yielded to toothless legal formalism within a matter of a few years. ${ }^{85}$ Nevertheless, many precincts

84. Lauren Berlant \& Michael Warner, Sex in Public, 24 Critical lnquiry 547, 558 (1998). As if the liberty principle in Lawrence were in any respect ambiguous, Justice Kennedy seeks to reassure his colleagues and the public that with this opinion he is not ushering in a new era of sexual politics:

The present case does not involve minors. It does not involve persons who might be injured or coerced or who are situated in relationships where consent might not easily be refused. It does not involve public conduct or prostitution. It does not involve whether the government must give formal recognition to any relationship that homosexual persons seek to enter. The case does involve two adults who, with full and mutual consent from each other, engaged in sexual practices common to a homosexual lifestyle. The petitioners are entitled to respect for their private lives. The State cannot demean their existence or control their destiny by making their private sexual conduct a crime. Their right to liberty under the Due Process Clause gives them the full right to engage in their conduct without intervention of the government.

Lawrence v. Texas, 123 S. Ct. 2472, 2484 (2003).

85. For commentary on the limits of Brown, see Derrick Bell, Dissenting, in What Brown v. Board of Education Should Have Said: The Nation's Top Legal Experts Rewrite America's Landmark Civil Rights Decision (Jack M. Balkin ed., 2001); Gary Orfield \& 
of the movement for racial justice overvalued the formal legal desegregation agenda set in motion by Brown. At the same time, other activists pursued political goals that were not necessarily charted by Brown's normative frame. This experience, while not unique to the struggle for African American rights in the United States, illustrates how law has a particular power to shape the agendas and desires of movements that figure rights as one of their principal objectives. ${ }^{86}$ While legal narratives of rights unfolding in successive judicial opinions are constrained by the pulls of doctrinal coherence and fidelity to precedent, no such constraints govern the normative scope of the political. ${ }^{87} \ln$ this sense, the gay community's political projects post-Lawrence necessarily take place in the shadow of Bowers, but they owe it no fealty.

Lawrence announces that the criminalization of same-sex sodomy is unconstitutional because it interferes with gay people's right to enter into serious domestic relationships, but that should not be taken to define the political dimension of sexuality or sexual citizenship. Sex gets figured, if at all, in Lawrence as instrumental to the formation of intimate relationships-it seems not to have a social or legal status in its own right. As a result, sexual rights qua sexual are exiled from the legal struggle on behalf of gay men and lesbians.

Considering Lawrence from another vantage point, one could understand the Court's pre-Laurence jurisprudence as a form of hate speechconstitutionalizing and underwriting the power of a form of address that both labeled and constituted us abjectly. To be sure, Laurence signals the emergence of a new social existence for gays and lesbians. No longer will gay men and lesbians be interpellated in strict Althusserian terms as sodomites. This new social existence should not, however, be understood as a true, free nature being revealed now that the false and defamatory moniker "sodomite" has been constitutionally enjoined. Rather, gays and lesbians are subject to a new manner of address that in turn constitutes gay and lesbian subjects in terms set by that address. In Lawrence, gays are no longer recognized as sodomitic outlaws, but instead as civilized domestic subjects. ${ }^{88}$ Thus the horror of Bowers, expressed as hate speech, is ex-

Chungmei Lee, Brown at 50: King's Dream or Plessy's Nightmare? (Jan. 17, 2004), available at http://www.civilrightsproject.harvard.edu/research $/ \mathrm{reseg} 04 / \mathrm{resegregation} 04$. php (on file with the Columbia Law Review).

86. See Kristin Bumiller, The Civil Rights Society: The Social Construction of Victims (1988); Mark Barenberg, Democracy and Domination in the Law of Workplace Cooperation: From Bureaucratic to Flexible Production, 94 Colum. L. Rev. 753 (1994).

87. For a discussion of the ways in which law can crowd out extralegal strategies for social change, see Michael McCann \& Helena Silverstein, The "Lure of Litigation" and Other Myths About Movement Lawyers in the United States, in Cause Lawyering: Rights Politics and Professional Responsibility (Austin Sarat \& Stuart Scheingold eds., 1997).

88. The ECHR affirmed the criminal prosecution of gay men who engaged in sadomasochistic sex, in part, on the grounds that "[s]ociety is entitled and bound to protect itself against a cult of violence. Pleasure derived from the infliction of pain is an evil thing. Cruelty is uncivilized." Laskey v. United Kingdom, 24 Eur. Ct. H.R. 39, 43 (1997). 
changed in Lawrence for tolerance, if not respect, for a mimetically domesticated gay. 1t is vital that we bear in mind that state recognition does not merely impose legal order on "facts in the world." State ordering actually brings those facts into being in a range of ways, whether it be how individuals come to understand tbemselves in the shadow of law, ${ }^{89}$ by and through the law's summons, or by the state's creation of explicit and implicit incentive systems. While all this can be said of identity, it can also be said of the desires these subjects both experience and express. The present stampede toward marriage in the gay community provides ample evidence for a healthy suspicion of the ways in which state ordering itself fuels, if not creates, desiring subjects.

What I find remarkable about much of the leadership in the $1 / \mathrm{g} / \mathrm{b} / \mathrm{t}$ community - a fact that led it to exalt the Lawrence decision-is the yearning for official recognition. There is a fascination with law, with registration, and with demands for the state to both see gay people and to govern them in ways that fall within the peculiar repertoire of state governance. In this sense, many leaders in the gay community have exchanged one form of desire for another: The kind of desire that got John Lawrence and Tyron Garner into trouble in the first place has been parlayed into a desire of a different kind-a desire to marry and a desire for homosexual couples to be recognized by law and legal authorities, not to mention caterers, tuxedo rental shops, and wedding planners. The path away from illegitimacy in criminal law seems to lead immediately and exclusively toward legitimization through civil law. Yet the complexities of simultaneously exchanging one form of legal regulation of homosexuality for another play almost no role in contemporary gay political discourse. What these $1 / \mathrm{g} / \mathrm{b} / \mathrm{t}$ leaders somehow fail to appreciate is that gay and lesbian subjects are constituted by and through their manner of address, by and through the way they are recognized, registered, and brought within the jurisdiction of the state. That jurisdiction used to be criminal. Now it's civil in nature.

How has this come to be? How has this become a community that privileges recognition so highly, and seems to have abandoned some of the more radical strategies and goals grounded in a politics that sought to destabilize dominant forms of sexuality and kinship, rather than seeking to be stabilized by them? ${ }^{90}$ Might there be something politically valuable

89. See, e.g., Ariela R. Dubler, In the Shadow of Marriage: Single Women and the Legal Construction of the Family and the State, 112 Yale L.J. I641 (2003) (explaining that women outside the legal boundaries of marriage have nonetheless been regulated by its normative framework); Robert $\mathrm{H}$. Mnookin \& Lewis Kornhauser, Bargaining in the Shadow of the Law: The Case of Divorce, 88 Yale L.J. 950 (1979) (noting that divorce law provides a framework in which private couples can form their own private ordering regarding post-divorce rights and responsibilities).

90. Here, I am thinking about the early homophile movement led, in part, by Harry Hay as well as the feminist sexual radicals of the late 1970 s and early 1980 s, all of whom sought a more radical sexual politics than that imagined today. See generally John D'Emilio, Sexual Politics, Sexual Communities (1983); Pleasure and Danger: Exploring 
in resisting the transformation of the gay political subject from pervert to domesticated couple? What political projects are foreclosed by the vilification of the notion of perversion in the gay community? Why have the gaining of rights and the politics of recognition been substituted for earlier political goals in the gay community that were committed to making viable a range of sexual and kin affiliations other than those that are narrowly domestinormative?

One answer turns, I think, on the prominence of lawyers and legal strategies in modern $1 / \mathrm{g} / \mathrm{b} / \mathrm{t}$ organizing. Lawyers privilege the problem of legal classification-looking to law as at once the source of our oppression and the key to our liberation. That is to say, the harm suffered by gays and lesbians pre-Lawrence was understood as a problem of misrecognition, of their legal misclassification as sodomites. When you dispatch a bunch of lawyers to address the problem, the solution is to force law to classify us correctly. This move gives us two choices: first, to demand that law refocus its gaze such that we are seen accurately rather than through the distorting lens of intolerance. Under this account we get figured in law as victims who turn to law to remedy instances of social misrecognition that result in losing our jobs, our homes, our children, etc. This account risks our identification as victims. ${ }^{91}$

Alternatively, we make the move that any legal distinction is illegitimate-the homo equivalent of colorblind thinking in the racial equality context. In effect, this is the road down which Laurence travels. The orientation-blindness that underwrites this normative project at once accepts and erases the heteronormativity that is its underlying premise. Homosexual relationships are to be treated just as straight people's are, only to the extent that their relationships mimic heterosexuals'. Heterosexual relationships remain the normative baseline for considering which rights they might enjoy.

Why would we take it as a priori true that the expansion of rights necessarily promises greater freedom? What do we risk when our political agenda sets a horizon that has no greater depth of field than securing legal rights and recognition by the state? In this regard, we have something to learn from the experiences of African Americans who became rights-bearing subjects and who gained the power to legally marry for the first time in the period immediately following the close of the Civil War.

Female Sexuality (Carole S. Vance ed., 1984). This legacy has been taken up and further developed more recently by authors such as Leo Bersani, Homos (1995), Michael Warner, The Trouble with Normal: Sex Politics, and the Ethics of Queer Life (2000), Berlant \& Warner, supra note 84 , and writers in the Special Issue on Intimacy in volume 24 of Critical Inquiry (1998).

91. Wendy Brown's work on "wounded attachments" both captures and critiques this posture quite thoroughly, as does Patchen Markell's new work. Wendy Brown, States of lnjury: Power and Freedom in Late Modernity 52-76 (1995); Patchen Markell, Bound By Recognition (2003). 


\section{Historical Dilemmas of Marriage and Freedom}

Given their legal status as chattel and not persons, enslaved couples in the antebellum South did not have the power to enter into legally enforceable marriages. ${ }^{92}$ Just as gays and lesbians have done, enslaved people nevertheless lived together as husband and wife after undertaking wedding celebrations as simple as jumping over a broomstick, ${ }^{93}$ or as elaborate as a "Scripture Wedding" 94 or grand banquet thrown for the entire community. ${ }^{95}$ These couples considered themselves married in the eyes of God, the community, and in some cases, their owners. But, of course, they were not married in the eyes of the law. ${ }^{96}$

1t was taken for granted by virtually all significant political actors, and surely by enslaved people themselves, that emancipation would entail the power to marry. ${ }^{97}$ And indeed it did. Shortly after the end of the war, Southern states acted quickly to amend their constitutions or enact statutes validating the marriages of formerly enslaved people. Laws that simply legitimized these marriages, as long as the couple was cohabiting as husband and wife when the law went into effect, were quite common. Mississippi's 1865 civil rights law was typical: “[A]1l freedmen, free $\mathrm{Ne}$ groes and mulattoes, who do now and have heretofore lived and cohabited together as husband and wife shall be taken and held in law as legally married." 98

92. " $[W]$ e are deprived of every thing that hath a tendency to make life even tolerable, the endearing ties of husband and wife we are strangers to for we are no longer man and wife than our masters or mistresses thinkes proper marred or onmarred." Petition to the Governor, the Council, and the House of Representatives of Massachusetts (May 25, 1774), reprinted in 1 Herbert Apetheker, American Negro Slave Revolts 8-9 (1943), quoted in Peggy Cooper Davis, Neglected Stories: The Constitution and Family Values 109 (1997).

93. See Herbert G. Gutman, The Black Family in Slavery and Freedom, 1750-1925, at 275-77 (1979); Leon F. Litwack, Been in the Storm So Long: The Aftermath of Slavery 240 (1979); Ann Patton Malone, Sweet Chariot: Slave Family and Household Structure in Nineteenth-Century Louisiana 224 n.64 (1992).

94. Malone, supra note 93, at 224.

95. See id, at 225 ("When weddings were allowed, they became community observations and social occasions rivaled only by Christmas and end-of-harvest celebrations.").

96. See Gutman, supra note 93, at 275-77; Litwack, supra note 93, at 240; Malone, supra note 93 , at 224 n.64.

97. See Davis, supra note 92, at 108-17; Eric Foner, Reconstruction: America's Unfinished Revolution 82-84 (1988); Michael Grossberg, Governing the Hearth: Law and the Family in Nineteenth-Century America 133 (1985); Gutman, supra note 93, at 204-07; Malone, supra note 93, at 166; Noralee Frankel, Workers, Wives, and Mothers: Black Women in Mississippi, 1860-1870, at 146-47 (1983) (unpublished Ph.D. dissertation, George Washington University) (on file with the Columbia Law Review).

98. Civil Rights Act of Nov. 25, 1865, ch. 4, $\S 2,1865$ Miss. Laws 82, 82. Georgia, North Carolina, South Carolina, and Virginia passed similar laws during this period. See, e.g., Act of Mar. 9, 1866, tit. 31, $\$ 5,1866 \mathrm{Ga}$. Laws 239, 240 (prescribing and regulating the relation of husband and wife between persons of color); Act of Mar. 10, 1866, ch. 40, $\$ \S 1-5,1866$ N.C. Sess. Laws 99, 99-101 (concerning negroes and persons of color or of mixed blood); Act of 1865, 1865 S.C. Acts 291, 292 (establishing and regulating domestic 
Some states took a different approach to the marriage of formerly enslaved people, giving "all colored inhabitants . . claiming to be living together in the relation of husband and wife ... and who shall mutually desire to continue in that relation" nine months to formally remarry one another before a minister or civil authority. ${ }^{99}$ These laws further required newly married couples to file a marriage license with the county circuit court, a bureaucratic detail that carried a prohibitively high price for many freedpeople. ${ }^{100}$ In every state with such laws, failure to comply with these requirements while continuing to cohabit would render the offenders subject to criminal prosecution for adultery and fornication. ${ }^{101}$ North Carolina gave freedpeople just under six months to register their marriages with the county clerk. Each month they failed to do so constituted a distinct and separately prosecutable criminal offense. ${ }^{102}$

While many formerly enslaved people merely allowed the law to operate upon them, automatically legitimizing their marriages, others "swamped public officials with demands to validate old and new unions." ${ }^{103}$ Thus, the power to marry for African Americans in the immediate postbellum period had both symbolic and practical significancesymbolic in the sense that enjoyment of the power signaled acceptance into the moral community of civil society, and practical to the extent that social and economic benefits flowed from being legally married.

The sight of gay and lesbian couples overwhelming San Francisco's City Hall this February ${ }^{104}$ echoes the sheer delight, exuberance, even ecstasy with which formerly enslaved people overwhelmed local courthouses in search of marriage licenses in the immediate postbellum period. While these two political moments and these two constituencies are dis-

relations of persons of color, and amending the law in relation to paupers and vagrancy); Act of Feb. 27, 1865, ch. 18, $\$ 2,1865$ Va. Acts ch. 85 (legalizing marriages of colored persons now cohabitating as husband and wife), reprinted in June Purcell Guild, Black Laws of Virginia: A Summary of the Legislative Acts of Virginia Concerning Negroes from Earliest Times to the Present 33 (1996); see also Laws Relating to Freedmen, Compiled by Command of Major General O.O. Howard, Commissioner, Bureau of Refugees, Freedmen and Abandoned Lands, S. Exec. Doc. No. 39-6, at 179 (1866) (collecting Black Laws assembled by the head of the Freedman's Bureau and submitted to Congress in 1866-1867).

99. Act of Jan. 11, 1866, ch. 1469, § 1, 1865 Fla. Laws ch. 31.

100. North Carolina entitled the county clerk to charge the newlyweds a fee of twentyfive cents for the task of filing a certificate of marriage. See Act of Mar. 10, 1866, ch. 40, $\S 5,1866$ N.C. Sess. Laws at 101. In 1866, twenty-five cents was an amount of money that put nuptial legitimacy well outside the reach of most African Americans.

101. See, e.g., Act of Dec. 14, 1866, ch. 1552, $\$ 1,1866$ Fla. Laws ch. 22.

102. See Act of Mar. 10, 1866, ch. 40, $\$ 6,1866$ N.C. Sess. Laws at 101.

103. Grossberg, supra note 97 , at $133-34$ ("In 1866 over 9,000 couples registered their marriages in seventeen North Carolina counties."); see also Litwack, supra note 93, at 240-41 ("Whatever the most compelling reason, mass wedding ceremonies involving as many as seventy couples at a time became a common sight in the postwar South.").

104. Miguel Marquez, More than 1,600 Same-Sex Marriages Performed, Feb. 15, 2004, at http://www.cnn.com/2004/US/West/02/15/same.sex.marriageindex.html (on file with the Columbia Law Review). 
similar in significant respects, there is something valuable for us to learn in the present moment by studying the experiences of African Americans when they too were first granted the power to become husbands and wives.

First of all, formerly enslaved people had developed a range of kin formations in the antebellum period. Some have traced the variety of forms of intimacy, family, and kinship to African roots, to dysfunctional adaptation to the cruelty of enslavement, or to something distinctly wonderful about black culture. ${ }^{105}$ The ability to marry rendered many of these forms of intimate, domestic, and sexual life nonnormative, and worse, illegal. Some black women believed that they could have more than one husband, since the forced separation of enslaved families had meant that many people undertook serial marriages as their spouses were sold away. Black women had a hard time accepting that they couldn't be married to all the fathers of their children-all the men they had loved and lost. ${ }^{106}$ So too, the substantive and procedural requirements of legal divorce were underappreciated by many people, who extralegally broke off with a spouse when the marriage failed and began another relationship with someone else. These practices rendered many former slaves vulnerable to prosecutions for adultery, bigamy, and fornication, crimes that were felonies in many jurisdictions. ${ }^{107}$ Many people quickly learned that legal subjectivity entailed not only power, but responsibility and attendant punitive sanctions for intentional or naive transgressions of the law. In this period, as well as in the present moment, becoming legitimate can be "an ambivalent gift," as Judith Butler has noted, ${ }^{108}$ to the extent that the process by which styles of life become legitimized can, and often must, entail the delegitimization of other ways of being.

The African American postbellum experience also warns us that the price of delegitimization is not one levied only by the state. While local police and district attorneys were criminally prosecuting black people who violated the rules of marriage and divorce, many black men and women set to work on the project of enforcing respectability norms in their own communities. Laura Edwards notes:

Many African-American leaders were quite aware that white northerners and southerners alike used marriage as a barometer of their people's fitness for freedom, and they urged poor blacks to adopt the domestic patterns common among elite whites.

105. For a discussion of the variety of kinship formations developed by enslaved people and the theories that sought to explain them, see Katherine M. Franke, Becoming a Citizen: Reconstruction Era Regulation of African American Marriages, 11 Yale J.L. \& Human. 251, 258-74 (1999).

106. Id. at 283 n.152.

107. ld. at $285-88$.

108. Butler, supra note 77 , at 232 . 
This, they argued, would help convince the nation that ex-slaves deserved the rights and privileges of freedom. ${ }^{109}$

In support of this effort, one African American leader argued, "[1]et us do nothing to re-kindle the slumbering fires of prejudice between the two races. Remember, we are on trial before the tribunal of the nation and of the world, that it may be known ... whether we are worthy to be a free, self-governing people." 110

Thus, it was not uncommon for "respectable" members of the community to turn in their erring brothers and sisters to white legal authorities if they were known to be cohabitating without marrying, maintaining more than one spouse, or violating the obligations of marital monogamy. ${ }^{111}$ In addition, close examination of the papers supporting arrest warrants and the witnesses who testified to grand juries in connection with the prosecution of black men for bigamy or adultery reveals that these prosecutions were initiated by the wives of these men. These newly emancipated women had been automatically married to their husbands through continuous cohabitation or in some cases had gone through the formalities of obtaining a marriage license. Their husbands, however, had taken up with other women and the first wives had resorted to criminal legal authorities either to punish their men or to try to get them back. The extant documents unfortunately do not reveal the women's motiva-

109. Laura F. Edwards, Gendered Strife and Confusion: The Political Culture of Reconstruction 56 (1997).

110. Id. (citation omitted) (quoting James H. Harris). Immediately after the war, Federal Freedmen's Bureau officers also compiled lists of exemplary African American men who might be appointed to various political offices in the military governments set up by the Bureau after Congress passed the first Reconstruction Act. See Richard Lowe, The Freedmen's Bureau and Local Black Leadership, $80 \mathrm{~J}$. Am. Hist. 989 (1993). Lowe argues that the "black men who, in [the Bureau's] opinion, had demonstrated some ability and capacity for leadership in the two years since the end of slavery," were more than likely light-skinned. Id. at 992 . Bureau agents explicitly disfavored "black men who had already established a reputation for alienating the native white community." 1d. at 995 . Thus, Lowe concludes, the "black leaders" listed by Bureau officers were not, in many cases, the people whom the Black community would have identified had they been asked. Here, as elsewhere, the freedmen who won the praises of white military and civilian authorities served as examples against which "bad blacks" were unfavorably compared for refusing to play within the bounds of white supremacy and Victorian ideology.

111. The Criminal Action Papers from Granville County, North Carolina for the years 1869-1876 provide an example of this dynamic. The number of prosecutions for fornication and adultery increased substantially in 1875, and many of these cases involved black people. The papers show Willis and Chaney Chandler, a black couple, as complaining witnesses on the indictments of other members of the black community. These documents leave the impression that the Chandlers were actively cooperating with the local police by ferreting out "marital outlaws." Ironically, Willis and Chaney Chandler appear on an indictment in July of 1875 , not as witnesses but as defendants-it appears they too had not been formally married. Indictment-Fornication and Adultery, State of North Carolina, Granville County Superior Court, July 1875, Granville County Criminal Action Papers, 1873-1875, North Carolina State Archives, Raleigh, North Carolina (on file with the Columbia Law Review). 
tions for turning their husbands in to local law enforcement on bigamy or adultery charges. 112

While acknowledging the substantial distinctions between the circumstances of freedpeople in the immediate postbellum period and gays and lesbians today, I offer this parallel experience in order to illuminate some of the risks in pursuing a civil rights program that places too much emphasis on state-based recognition and legal legitimization. At a time when formerly enslaved people sought to create distance between themselves and white authority (whether it be private or public authority), many of them assumed that the "freedom to marry" meant that they would be able to set the terms and conditions of marriage independent of state oversight. What they didn't realize was that the "freedom" they gained in the power to marry had the effect of bringing them into a closer relationship with the state-a relationship that empowered the state to govern the intimate and kin relations that freedpeople were making outside the bounds of enslavement. Thus, they too exchanged one extremely harsh form of legal regulation-enslavement-for another in the form of marriage, and shortly thereafter, contract labor. In many important respects, freedom for the newly emancipated people of the South meant being embedded in a web of legal rights and powers-the power to marry, the right to alienate their labor according to the contract labor system, and the right to acquire debt, for example. Freed men and women quickly discovered that, in many respects, the liberty rights they were enjoying for the first time ended up forming the basis of a new kind of governance-governance by the state, governance by private employers, governance by "respectable" members of the community, all designed to incentivize seIf-governance. So too, the project of "civilizing" freed men and women through law entailed the cultivation of a range of desires-desires for rights, desires for a bourgeois form of marriage grounded in monogamy and domesticity, desires for legal subjectivity even when that status was delivered explicitly as an alternative to the allocation of material resources to freed men and women.

This account also illustrates the capillary nature of state regulation and power during Reconstruction. Freedpeople interiorized an individu-

112. For example, Albert Watkins and Anna Williams were jointly prosecuted for bigamy by the Warren County District Attorney in Vicksburg, Mississippi in June of 1866. Indeed, their case was the first bigamy prosecution brought in the Vicksburg criminal courts when the civilian courts reopened after the Civil War ended. Albert had married Anna on June 8, 1866, and on that afternoon Albert's first wife, Josephine, filed a criminal complaint with the local sheriff. Josephine maintained that she and Albert had been automatically married by operation of law on November 25, 1865, when the Mississippi law relating to freedmen's marriages went into effect. See Civil Rights Act of Nov. 25, 1865, ch. $4, \S 3,1865$ Miss. Laws 82. In the end, both Albert and Anna were found not guilty. Affidavit of Josephine Watkins, col'd v. Albert Watkins, col'd, Bigamy, June 8, 1866, and Indictment State v. Albert Watkins, June 25, 1866; Indictment State v. Anna Williams F.W.C., June 25, 1866, Warren County Criminal Action Papers, Old Court House, Vicksburg, Mississippi (on file with the Columbia Law Review). 
alized sense of self-regulation characterized by punctuality, order, ambition, hard work, cleanliness, and domesticity. These technologies of the self became the credentials that Northern officials looked for when considering whether and, if so, when freedmen had proven themselves eligible for citizenship. "Being a free citizen, he must act as one, carrying the burdens, if he so considers them, as well as enjoying the privileges of his new condition," 113 cautioned the chief judge of the Georgia Supreme Court in 1881 .

\section{CONCLUSION}

Then as now, rights deliver their own peculiar form of practical freedom. Something more is required of the political subjects and communities that are making demands for rights. Then as now, we risk being recognized as rights holders only to the extent that we perform what David Scott calls "responsibilized" freedom, grounded in rationalized self-discipline. ${ }^{114} 1 \mathrm{t}$ is unquestionably true that many of the freed men or women who rushed to be married in 1865 and 1866, as well as the gay and lesbian couples that stood in the rain outside San Francisco's City Hall waiting for marriage licenses last February, experienced a real sense of rapture at the moment they were declared husband and wife, husband and husband, or wife and wife. My objective here is not to doubt the ecstasy these couples experience at these moments of state recognition, but rather to urge us to adopt a critical stance with respect to that ecstasy. We cannot not want it, but what is its price? What other forms of rapture, of belonging, of the self, are rendered less legible, less viable, and more marginal when the state credits some human affiliations as sacred? By demanding of public officials-"Are you for or against gay marriage?"-we have set up a binary with dangerous implications. Other forms of affiliation besides marriage, such as civil unions or domestic partnerships to name the most conventional alternatives, become positioned as the harbor of cowards and those who favor the cause too little. We have thereby foreclosed the exploration of family, intimate, sexual, and kin formations other than marriage. Securing social recognition for these other affiliations is regarded as either a compromise or a loss, notwithstanding the fact that these other forms of life provide viable sites in which to elaborate a self.

A politics that is limited to the acquisition of rights is not up to the ethical task of at once acknowledging the "unfreedom" that lies in denying same-sex couples the power to wed, while also recognizing the limits and costs of privatized liberty. While we celebrate the result in Lawrence, we should remain wary of the impulses and desires that are, in part, motivated by Justice Kennedy's reasoning.

1 am inclined to end with a prediction: Within a relatively short period, opposition to gay marriage will dissipate, but not because those who

114. David Scott, Refashioning Futures: Criticism After Postcoloniality 84, 87 (1999). 
now disfavor it will come around to the righteousness of the cause. Rather, it will subside because the decriminalization of sodomy and of gay and lesbian sexual relationships will have created a social terrain in which a vast number of sexual relationships will appear to stand outside the legal order altogether. ${ }^{15}$ This, I believe, will prove to be an unbearable state of affairs for those who have always favored the governance, surveillance, and supervision of sexuality. Bringing same-sex couples within the regulatory reach of marriage will in the not too distant future emerge as a better choice than leaving these sexual subjects in the underregulated space that lies between criminalization and legitimization through marriage. ${ }^{116}$

Who knows if I am right? But the fact that this prediction is entirely plausible should give the gay community pause in its rush to law, to recognition, and to state sanction. This regulatory middle ground and transitional space is precisely where Lawrence lands us. It is an uncharted territory that is worth exploring, and possibly expanding, rather than discrediting by virtue of its dissimilarity to domestinormative marriage.

115. Of course, many gay men and lesbians have and will continue to regard their formally unregulated relationships as being governed ethically and practically by the shadow of marriage. At the same time, many of those who oppose gay marriage fail to see marriage as an institution that casts a shadow of any kind-either you are part of the institution and live by its rules or you wander in the wasteland of iniquity.

116. This concern could be addressed in another way, I suppose. In 2000, the American Law Institute adopted new principles relating to the formation and dissolution of domestic partnerships, whether between same or different sex individuals. ALI, Principles of the Law of Family Dissolution: Analysis and Recommendations, ch. 6, at 907 (2000) ("Domestic Partnerships"). The ALI Principles recommend that courts adopt a default rule recognizing a domestic partnership if, among other things, two persons have maintained a joint household for a cohabitation period of possibly two or three years. 1d. $\$ 6.03(2)-(5), \S 6.03 \mathrm{cmt}$. d, at 916-17, 921. To escape the presumption in favor of a domestic partnership, the couple would have to have made an enforceable contract to the contrary, id. $\$ 6.03 \mathrm{cmt}$. b, at 919 , but they need not have reached a mutual explicit agreement between themselves that their relationship acquire this particular legal status. Id. Form, not intent, is fundamental here. If a relationship is found to be a domestic partnership, a wide range of rules will be applied to the parties relating to the distribution of property upon the termination of the relationship. See id. $\$ 6.04-.05$, at $937-41$. So, it is possible that the ALI's principles will do the trick of filling in much of the underregulated space that unmarried gay couples inhabit, and this will make many people, both gay and straight, quite happy.

Yet African Americans' experiences with automatic marriage illustrate the danger and discipline of these regulatory default rules. As gay men and lesbians creep ever closer to traditional marriage, and marriage rules migrate ever farther from the formal institution of marriage, smaller and smaller social space is left for those people who want to resist the default rules and norms of marriage. Unfortunately, Lawrence's domestinormativity will likely make this problem even worse by supporting the expansion of the shadow of marriage. 